\title{
Pseudo-imposex; male features in female volutes not TBT-induced (Gastropoda: Volutidae)
}

\author{
Cornelis Swennen ${ }^{1}$, Phusit Horpet ${ }^{2}$ \\ ${ }^{1}$ Faculty of Science and Technology, Prince of Songkla University, Pattani 94000, Thailand, swennen@wxs.nl \\ ${ }^{2}$ Technology for Marine and Coastal Resources Management Program. School of Engineering and Resources, \\ Walailak University, Nakon Si Thammarat 80160,Thailand,hphusit@wu.ac.th
}

Key words: Indo-Pacific, pollution, Melo, Cymbiola

\begin{abstract}
The occurrence of a penis in female gastropods of the superfamily Muricoidea (infraorder Neogastropoda) has commonly been accepted as an indicator of tributyltin (TBT) pollution. Some species seem less sensitive than others, and one belonging to the family Columbellidae has been reported that it lacks the imposex response. During a survey in South-east Asian waters, females of Cymbiola nobilis and Melo melo (family Volutidae) with a small penis and an external vas deferens were initially considered as showing imposex. Doubt arose when $100 \%$ of the females had a penis on sites where other gastropods showed no or a low imposex incidence. During the present study, several hypotheses could be rejected such as (1) that the volutes are extremely sensible for TBT; (2) due to a high age they have a higher chance of coming into contact with TBT; or (3) they have a sex change during growth. This induced us to search for museum specimens collected before 1960, which date is long before TBT was brought into use as biocide in anti-fouling paint on ships. In the Australian Museum in Sydney and the Zoological Museum in Amsterdam some species were found from Indonesian and Australian waters. All inspected females showed the typical small penis and vas deferens by which it became clear that it is not TBT induced, but a natural phenomenon in these species. This is unknown in other muricoids. The "pseudo-imposex" has been established in Cymbiola nobilis, C. vespertilio, Melo amphora, M. melo and M. umbilicata. These species belong to the Volutidae subfamily Cymbiinae. However, male characters in females seem missing in species belonging to the subfamilies Odontocymbiolinae and Zidoninae from South America; they show a normal TBT- induced imposex response according recent literature.
\end{abstract}

\section{Contents}

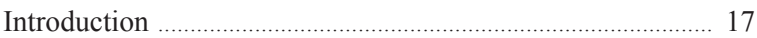

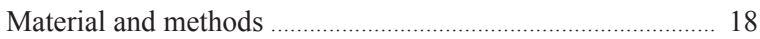

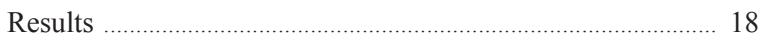

Sizes, sex and penis lengths of

live specimens 18

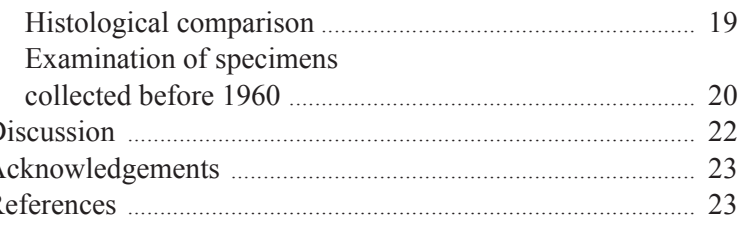

\section{Introduction}

Snails of the superfamily Muricoidea (Infraorder Neogastropoda) are dioecious. The sexes are externally distinguishable by the presence of a non-retractile penis and a vas deferens in males and a vaginal aperture in females. Abnormalities have been reported since the end of the 1960s when females of Nucella lapillus (Linnaeus, 1758) were found with a small penis (Blader, 1970). Gradually more marine gastropod species were discovered of which the females could show a small penis. Initially it was called masculinization or pseudo-hermaphroditism, but it soon became known as "imposex". It has been demonstrated that the aberration was caused by the use of tributyltin (TBT) as biocide in anti-fouling paints on ships (Smith, 1981; Gibbs and Bryan, 1986; Oehlmann et al., 1993; Mensink et al., 1996).

The occurrence of a penis in female gastropods has nowadays commonly been accepted as an indicator of TBT pollution (Gibbs et al., 1987; Oehlmann et al., 1996). Monitoring of gastropods has indicated that the abnormality can be found on all continents in the surroundings of harbours (Ellis and Pattisina, 1990; Horiguchi et al., 1991; Stewart et al., 1992), but also around shipping routes in the open sea such as the North Sea (Ten Hallers-Tjabbes et al., 1994) and in the Strait of Malacca and the Gulf of Thailand down into the deepest possible sampling sites (Swennen et al., 
1997). TBT has become a global pollution problem in marine habitats.

The present authors participated in the study in South-east Asian waters (Swennen et al., 1997). In that survey specimens belonging to the family Columbellidae were excluded, because it was reported that at least one species lacks the imposex response (Gibbs et al., 1997). No reports could be found indicating the reverse, namely the presence of a minipenis and vas deferens in female Muricoidea not imposed by organotin compounds. To be sure that this does not occur, species of which all females showed a penis during that survey were tested afterwards by searching them in sites were other species showed no imposex. Two species both belonging to the Volutidae failed the test. Females of Cymbiola nobilis (Lightfoot, 1786) and Melo melo (Lightfoot, 1786) showed a small penis and an external vas deference in areas where other species showed no sign of imposex. Therefore these volutes were considered as either extremely sensitive or the presence of male characteristics was a normal phenomenon in these species (Swennen et al., 2001). Two more hypotheses originated while digging further into this problem. Both species are the largest gastropods in the Gulf of Thailand, therefore it could be that due to their size and possible high age they could accumulate enough TBT to trigger the imposex response in areas where small species show no reaction. A fourth hypothesis of a sex change during growth arose when the few available data were compared in which the females were much larger than the males.

To study these four hypotheses, we collected live specimens of Cymbiola nobilis and Melo melo from various sites in the Gulf of Thailand. Both species seem nowhere abundant, but they are widely distributed over areas with a sandy bottom. Both have large and strong shells, no operculum, and often hiding themselves by totally burying into the sediment.

\section{Material and methods}

Live specimens of Cymbiola nobilis and Melo melo were collected from local fishing boats in 49 Thai fishing harbours and fish-landing places in the Gulf of Thailand between Sattahip $\left(12^{\circ} 39^{\prime} \mathrm{N}, 100^{\circ} 53^{\prime} \mathrm{E}\right)$ and Tak Bai $\left(6^{\circ} 39^{\prime} \mathrm{N}, 103^{\circ} 03^{\prime} \mathrm{E}\right)$ when the opportunity arose. Specimens of other volute species could be inspected near Townsville $\left(19^{\circ} 13^{\prime} \mathrm{N}, 146^{\circ} 47^{\prime} \mathrm{E}\right)$ in northeast Australia. Collected specimens were checked for shell size, length and structure of male and female pe- nis, and for the relation of these parameters to their sampling site. When a specimen was obtained, the height of the shell was measured. Then a part of the shell was removed by hammering to identify the sex and the penis measured. Because a penis and a vas deference occurred in males as well as in females, the presence or absence of the easily recognisable capsule gland in females was used to internally identify the sex of a specimen.

For histological comparison between male and female penis, five male and five female specimens of Melo melo were relaxed and stupefied in a solution of $72 \mathrm{~g} \mathrm{MgCl}_{2}$ in $1000 \mathrm{ml}$ water. Then the shell was removed and the penis and gonads preserved in a seawater/Bouin solution. Then these organs were paraffinembedded and sagittal and longitudinal sections were made of 3-5 $\mu \mathrm{m}$ thickness, stained with haematoxilin and eosin and enclosed in Permount. The sections were studied under a light microscope.

At the end of this study, attempts were made to locate Volutidae samples from before the 1960s, that is before the time that TBT in anti-fouling paints came in use.

\section{Results}

Sizes, sex and penis lengths of live specimens

From all over the Gulf of Thailand, 222 live specimens of Cymbiola nobilis and 99 of Melo melo have been collected for this study. Young, small specimens $(<60$ $\mathrm{mm}$ shell height) were missing in the samples as result of the large-mesh nets used by the fishing boats. Mean size of males was indeed smaller than in females. In Cymbiola nobilis the maximum height of the shells of males was $99 \mathrm{~mm}$ and of females $156 \mathrm{~mm}$ (Fig. 1) and in Melo melo the maximum shell height of males was $170 \mathrm{~mm}$, while the largest female came to $242 \mathrm{~mm}$ (Fig. 2). All males and females of both species had a penis behind the right tentacle and a pallial vas deferens that ran into a ridge between the base of the penis and the body wall near to the anus. The latter is located in the fold between the free part of the mantle and the body. In the same sex, the relative penis index (penis length in relation to shell height) in both species showed no differences among collecting sites, which covered areas with different imposex incidences in other species (Figs 1-2).

The male penises in Cymbiola nobilis and Melo melo were muscular and rigid. They had a strong integument like that over the exposed part of the body. In 
both species the male penis was curved and pointing in caudal direction. In Cymbiola nobilis a narrow groove ran from the tip to the connection with the ridge of the vas deferens and continued over the ridge to where it ends in the connection of the free part of the mantle and the body; this groove was shallow and locally absent in Melo melo. In Cymbiola nobilis the pigmentation of the exposed sides of the penis consisted of orange spots on a blackish brown background similar to other parts of the body. In Melo melo the pigmentation of the penis consisted of dark red-brown length-wise stripes on a yellowish background similar to the zebra-striped other parts of the body. Each penis was in cross-section more or less rounded at the base, but then oval, while it is more flattened towards the narrow tip without becoming a clear flagellum. Major differences were noticeable between the sizes of the male and female penises. The lengths of the female penis in Cymbiola nobilis measured on average $12 \%$ and of Melo melo $24 \%$ of the length of the penis of males of the same shell size (Figs 1-2). In both species the female penis and the ridge of the pallial vas deferens were in shape, groove and pigmentation miniatures of these organs in males (Fig. 3). Specimens of Melo umbilicata (Broderip, 1826) were collected at Parallenda beach, Townsville in Australia. Three of them were females, they showed also a small penis and vas deferens like imposex while no imposex was noted in any of the hundreds specimens of TBTsensitive species such as Thais kieneri Deshayes, 1844 as found by Evans et al. (1995) and Morula marginalba (De Blainville, 1832) as found by the second author.

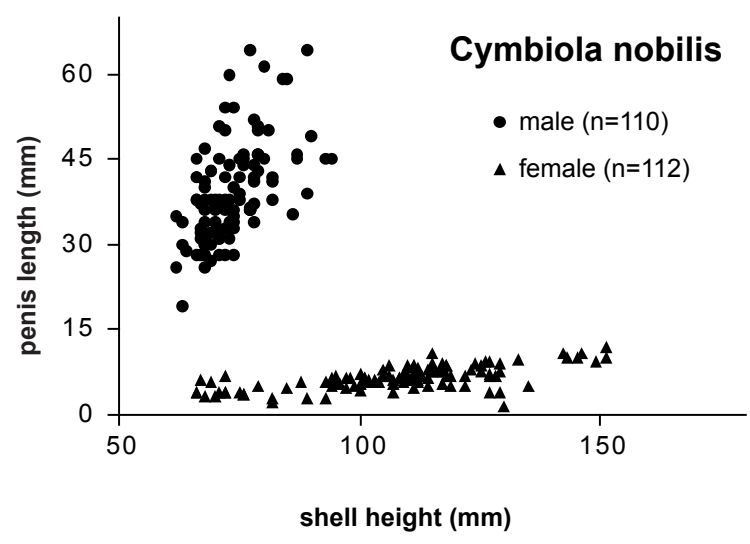

Fig. 1. Length of penis in relation to shell height and sex of live specimens of Cymbiola nobilis. Combined samples from the Gulf of Thailand.

\section{Histological comparison}

Cross-sections of the penises of males of Cymbiola nobilis and Melo melo showed a pigmented epidermis around unpigmented loose connective tissue. The epidermis seems thicker in Cymbiola nobilis than in Melo melo. In the connective tissue were found the penial duct (vas deferens) and one large and some small channels without a clear lining that may be blood channels. In most specimens, the lumen of the penial duct was crescent-shaped. The lumen of the penial duct was lined by a single layer of columnar epithelial cells with cilia surrounded by a layer of circular muscle fibers. The penial duct was connected over its whole length with the external integument by a band of fused epithelium at the site of the external groove (Figs 4-5). The penial duct ran slightly undulating to the penis tip. The connective tissue was more and more reduced towards the tip by which the penial duct seemed in the integument adjacent to the groove. Cross-sections of the ridge of the vas deferens on the body wall showed that the duct had the same structure as in the penis. It had also a connection of fused epithelium with the groove over its whole length. The distance to the epidermis showed some variation over the length of the tract.

The internal characters of penis and vas deferens in females of both species were similar to those of the males, but less developed and on a strongly reduced scale. The diameters of the penial ducts measured in the microscopic slides varied between 2.57 and 3.12

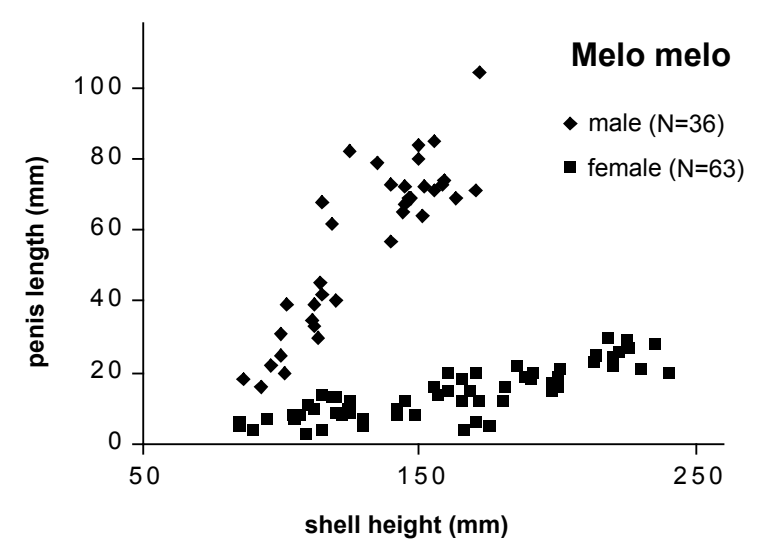

Fig. 2. Length of penis in relation to shell height and sex of live specimens of Melo melo. Combined samples from the Gulf of Thailand. 

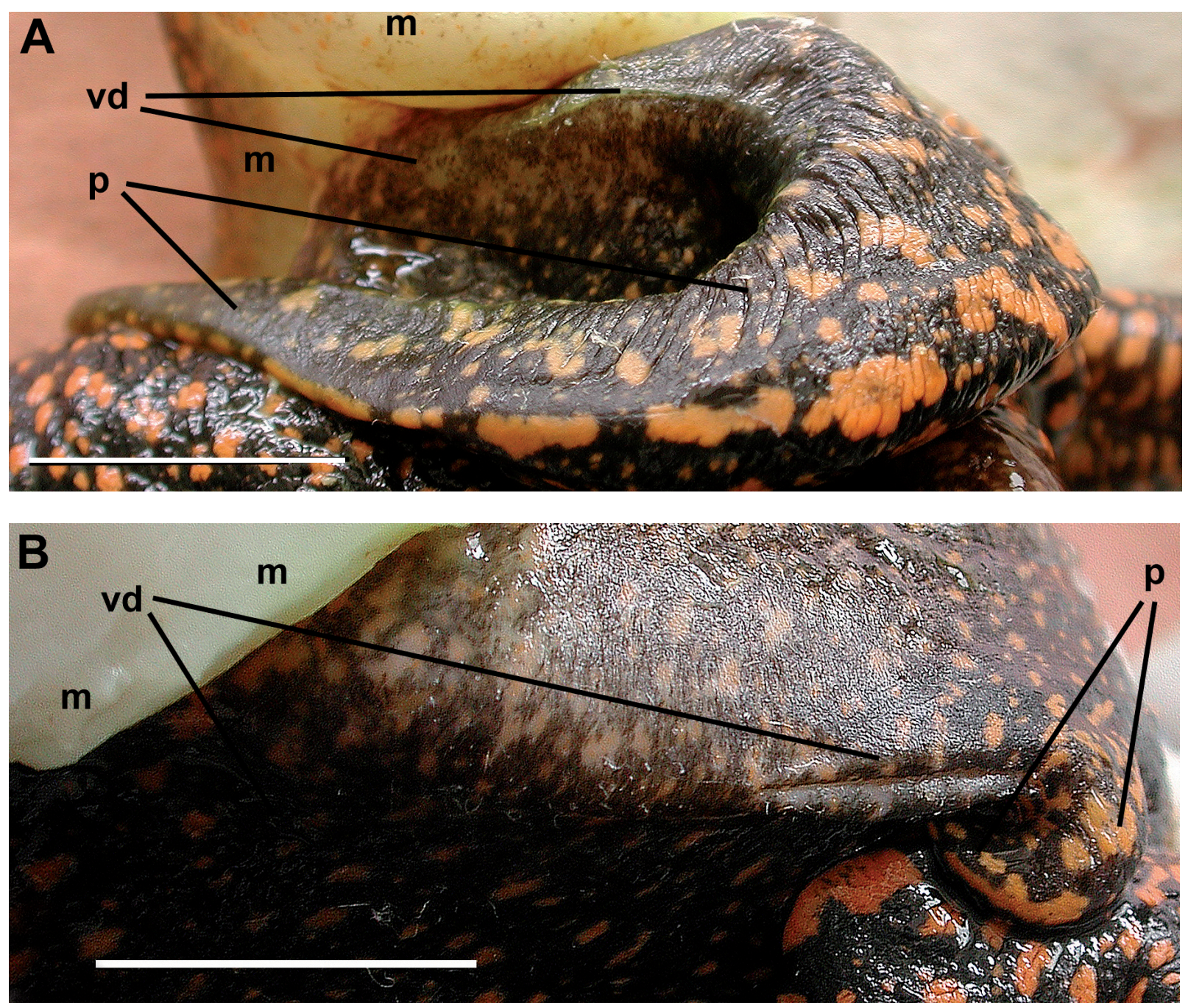

Fig. 3. Penises and ridges of the vas deferens of male and female Cymbiola nobilis (A, B) and Melo melo (C, D). Shell heights 85, 88, 158 and 162 respectively. A part of the oral velum is visible on the right side ventral of the penis in A, B, and C. Legend: $p=$ penis; vd = ridge of vas deferens, $\mathrm{m}=$ mantle or mantle border. The length of the white bar is $20 \mathrm{~mm}$.

$\mathrm{mm}$ in males and between 0.7 and $1.1 \mathrm{~mm}$ in females of both species. The capsule gland and other internal reproductive structures in females were found to be normal. Other abnormalities than the presence of a small penis and a pallial vas deferens were not found.

\section{Examination of specimens collected before 1960}

Suitable samples were found in the wet collections of the Australian Museum in Sydney and the Zoological Museum of the University of Amsterdam. Six old samples of Volutidae could be studied in Amsterdam:

1. Cymbiola nobilis (labelled as Voluta scapha Gmelin,
1791, which is a junior synonym), originating from Pulau Bintan, about $1^{\circ} 00^{\prime} \mathrm{N}, 104^{\circ} 30^{\prime} \mathrm{E}$ in Indonesia. Collected "Before 1930". Shell height was $119 \mathrm{~mm}$, female with a penis length of $2.9 \mathrm{~mm}$ and a ridge of the vas deferens from the base of the penis to the female aperture at attachment of the mantle border.

2. C. nobilis (labelled as Voluta scapha), same site and date as no. 1. Shell height $111 \mathrm{~mm}$. Female, length of penis $2.0 \mathrm{~mm}$, vas deferens as above.

3. Cymbiola vespertilio (Linnaeus, 1758) (labelled as Voluta vespertilio) collected on a coral bank at a depth of one fathom in the Bay of Riung, North coast of Flores, at $121^{\circ} 2^{\prime} \mathrm{E}$, Indonesia, in October 

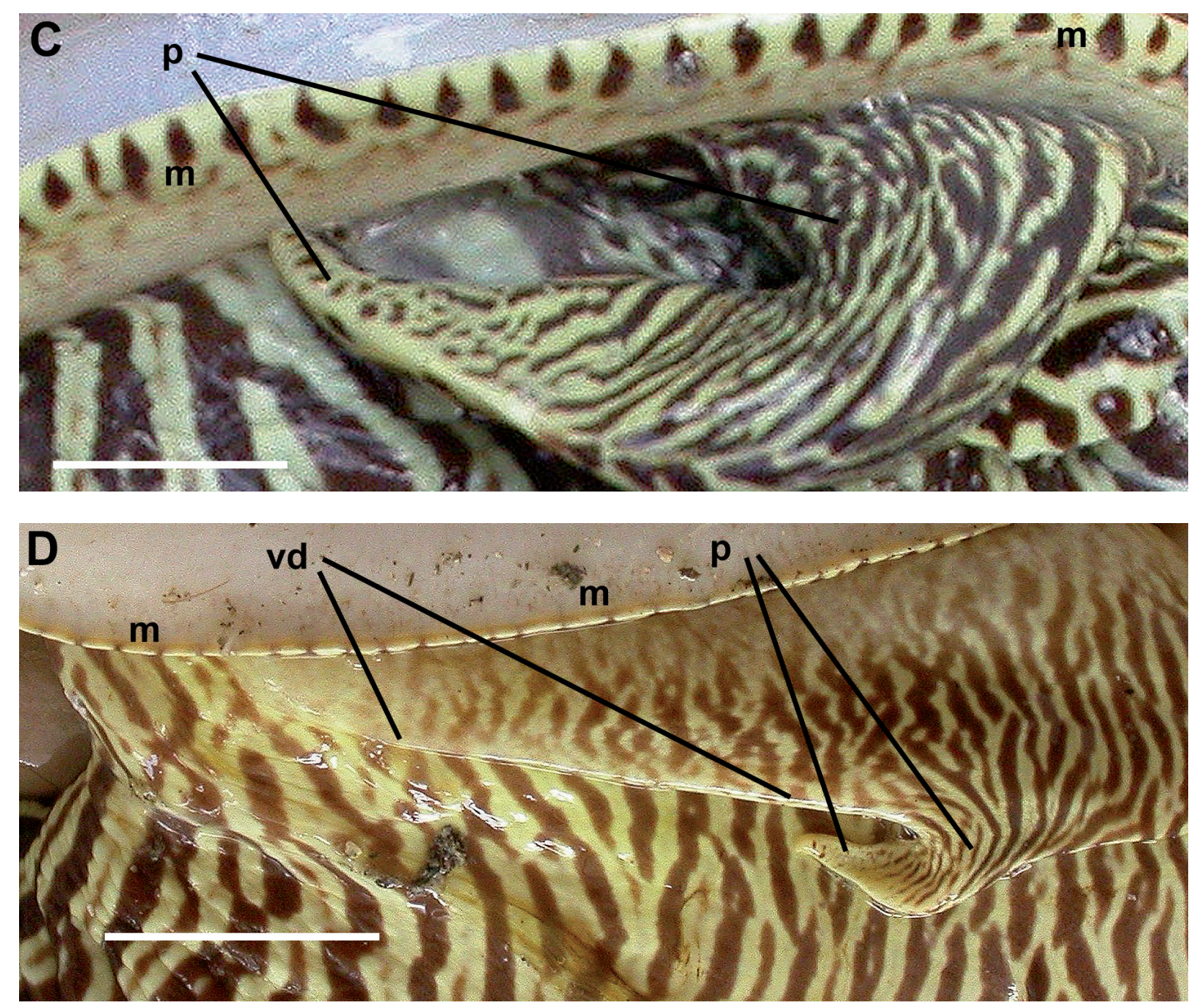

1908. Legit Van der Sande. Shell height 57.2 mm. A male with a penis length of $18.6 \mathrm{~mm}$.

4. C. vespertilio with the same info as no. 3. Shell height $71.2 \mathrm{~mm}$. A female with a mini-penis length $1.8 \mathrm{~mm}$, and a ridge of the vas deferens much thinner than in the male.

5. C. vespertilio collected near Kaimana on the southwest coast of Nieuw Guinea (West Papua), Indonesia, on 28 August 1910. Legit Minkema. Shell height $68.7 \mathrm{~mm}$. A female with a mini-penis of 2.9 $\mathrm{mm}$. Ridge of vas deferens as in no. 4.

6. Melo sp., likely Melo amphora (Lightfoot, 1786). The sample consisted of only soft parts and a colu- mella of a large shell. West coast Nieuw Guinea (now West Papua), Indonesia, 1904. Legit Dr. Koch. One female with a mini-penis of a length of about $11 \mathrm{~mm}$. A high vas deferens ridge that ended before the attachment of the mantle border. The condition of the material did not allow to take the sample out of the bottle to inspect the other specimens.

In the Australian Museum, four female specimens of Melo amphora were found. They had a shell height of about $95 \mathrm{~mm}$ and were collected in Morton Bay, near Port Look out, Queensland, Australia. January 1934, Ref. C98826: Legit Mrs. Durbridge. All showed a small penis and a pallial vas deferens ridge. 


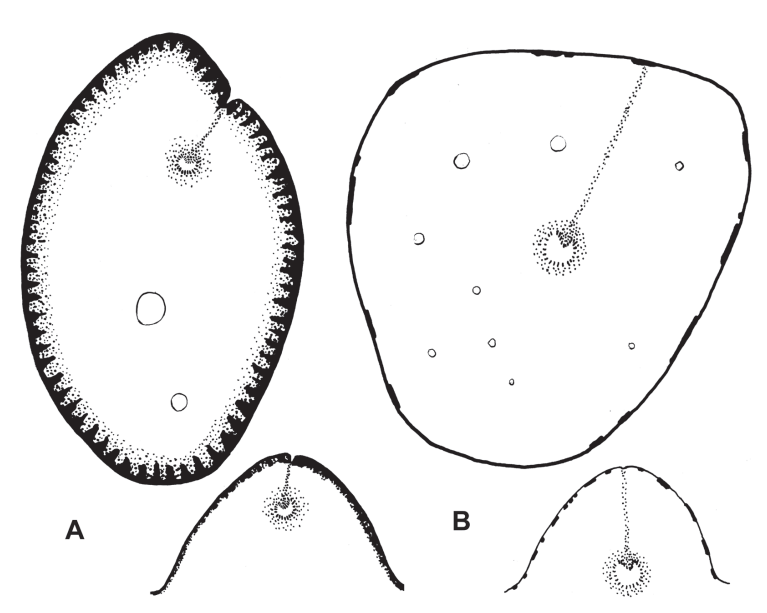

Fig. 4. Cross-sections of penis (upper row) and vas deferens ridge (lower row) of males of Cymbiola nobilis (A) and Melo melo (B).
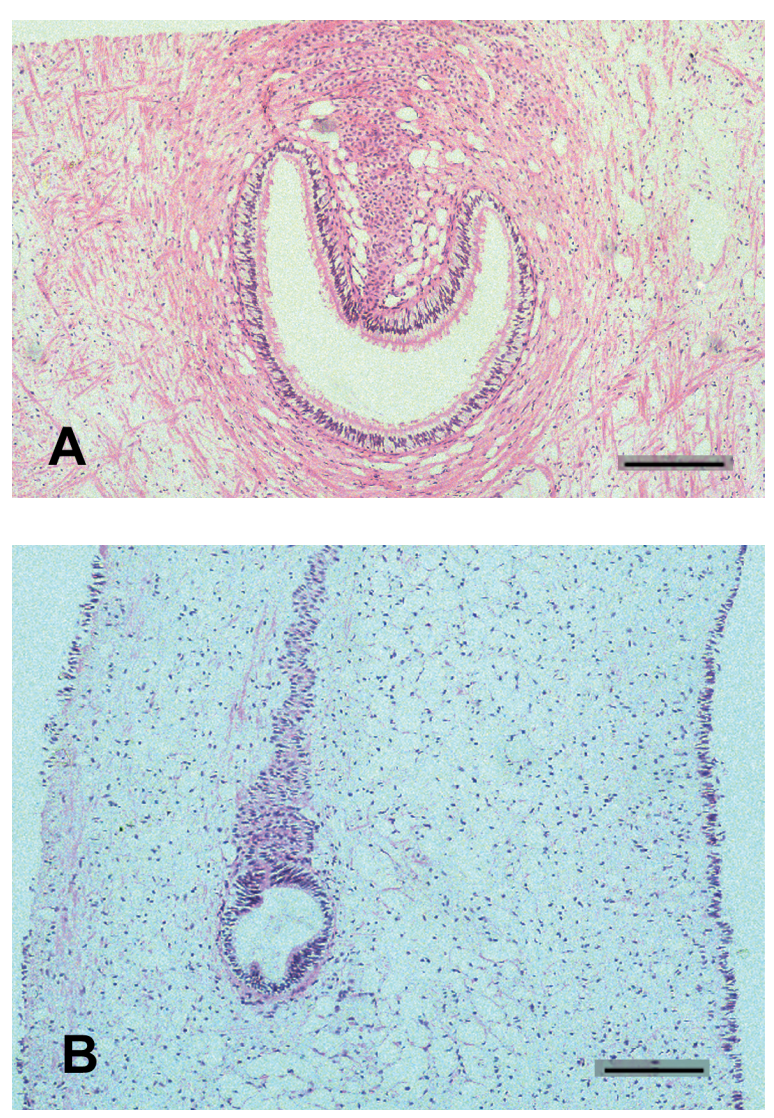

Fig. 5. The penial duct in the penis of a male (A) and a female (B) Melo melo.

\section{Discussion}

It is obvious that all female specimens of Cymbiola nobilis and Melo melo possess a penis and that the length of the male and female penises increases with shell size. The female penises do not show a variation in relative sizes according to the area where they occur. Such variation often happens in imposex-induced penises in some species of the Muricidae and Buccinidae and is expressed as relative penis size index (RPSI). The RPSI can be used for indicating slight differences in TBT pollution (Prouse and Ellis, 1997). It appears that females of Cymbiola nobilis and Melo melo reach a considerably larger size than males. Both sexes occur among small specimens (Figs 1-2), which rejects the hypothesis of a sex change during growth. Finally, the discovery of similar penises in female specimens of Cymbiola nobilis, C. vespertilio, Melo amphora, and M. melo collected before 1960, which is long before the TBT became in use as biocide in antifouling paints, shows that the occurrence in these Volutidae can be considered as a natural phenomenon.

The penis and vas deferens in females of Cymbiola nobilis and Melo melo are externally and internally similar to these organs in males except in size. The same has been found in TBT-induced imposex by Oehlmann et al. (1991) in Hinia reticulata (Linnaeus, 1758), and by Gibbs and Bryan (1986) and Stroben et al. (1992) in Nucella lapillus. Therefore it seems impossible to determine whether a mini-penis in a female snail is TBT induced or a natural phenomenon as found in some specific species in this study.

The development of a penis and a pallial vas deferens seems intrinsic in males and females and the expression may be hormonally induced. TBT will change the hormonal balance by which these organs become partly to expression in females, but indications of a total sex change induced by TBT have not been found. A similar hormonal situation as induced by TBT seems a natural phenomenon in a some gastropods belonging to the Volutidae, which can be called "pseudo-imposex". The finding of "pseudo-imposex" in Cymbiola and Melo does not mean that all Volutidae show this phenomenon. TBT-induced imposex has been found by Bigatti and Penchaszadeh (2005) in Odontocymbiola magellanica (Gmelin, 1791). These authors noted that specimens from Patagonia (Argentina) show a wide range of imposex incidences and relative penis sizes in relation to shipping. Goldberg et al. (2004) and Cledon et al. (2006) reported respectively up to 50 and up to $80 \%$ imposex in Adomelon brasiliana (Lamarck, 1811) near Mar del 
Plata (Argentina). The difference between these South American species and the Volutidae species studied in this paper may be at the level of the subfamily; Cymbiola and Melo belong to the Cymbiinae, Odontocymbiola magellanica to the Odontocymbiolinae and Adomelon brasiliana to the Zidoninae (Vaught, 1989).

Determining imposex incidence is a relatively quick and cheap method to establish occurrence, patterns and changes in TBT pollution. The present study shows that not all muricoids can be used for imposex determination. TBT-induced imposex can only be supposed when incidence and RPSI varies among sites parallel within species belonging to other families such as $\mathrm{Mu}-$ ricidae, Nassariidae, etc. When the occurrence of a penis in females is always $100 \%$ and RPSI invariable, then one may have found a similar case as described in this paper. Up to now two wrong imposex identifications have been found in the literature. One female Cymbiola nobilis and one female Melo melo have provisionally been considered as showing imposex in Swennen et al. (1997). On a total of 1164 females of various species, these two specimens do not affect the conclusion about the distribution of imposex in that paper. The other is the report of imposex in M. melo in the South China Sea by Shi et al. (2005).

\section{Acknowledgements}

The authors like to thank Nukul Ruttanadakul for facilitating our study, Sathit Ponkoon and Somsak Buatip for their help in the field. We thank also Robert Moolenbeek for allowing the study of pre-1960 specimens in the collection of the Zoological Museum Amsterdam, Ian Loch and Ms Alison Miller for their help with checking pre-1960 wet and dry specimens at the Australian Museum, and the anonymous referees for their detailed comments that helped the authors to improve the final draft.

\section{References}

Blader SJM. 1970. The occurrence of a penis-like outgrowth behind the right tentacle in spent females of Nucella lapillus (L.). Proceedings of the Malacological Society, London 39: 231-233.

Bigatti G, Penchaszadeh PE. 2005. Imposex in Odontocymbiola magellanica (Caenogastropoda: Volutidae) in Patagonia. Comunicaciones de la Sociedad Malacologica del Uruguay 88: 371-375.

Cledon M, Theobald N, Gerwinski W, Penchaszadeh PE. 2006. Imposex and organotin compounds in marine gastropods and sediments from the Mar del Plata coast, Argentina. Journal of the Marine Biological Association of the U.K., 86: 751755.
Ellis DV, Pattisima LA. 1990. Widespread neogastropod imposex: a biological indicator of global TBT contamination? Marine Pollution Bulletin, 21: 248-253.

Evans SM, Dawson M, Day J, Frid CLJ, Gill ME, Pattasina LA, Porter J. 1995. Domestic waste and TBT pollution in coastal areas of Ambon Island (Eastern Indonesia). Marine Pollution Bulletin 30: 109-115.

Gibbs PE, Bryan GW. 1986. Reproductive failure in populations of the dog-welk, Nucella lapillus, caused by imposex induced by tributyltin from antifouling paints. Journal of the Marine Biological Association of the U.K. 66: 767-777.

Gibbs PE, Bebianno MJ, Coelho MR. 1997. Evidence of the differential sensitivity of neogastropods to tributyltin (TBT) pollution, with notes on a species (Columbella rustica) lacking the imposex response. Environmental Technology 18: 1219-1224.

Gibbs, PE, Bryan GW, Pascoe PL. Burt GR. 1987. The use of the dogwelk, Nucella lapillus, as an indicator of tributyltin (TBT) contamination, Journal of the Marine Biological Association of the U.K. 67: 507-523.

Goldberg RN, Averbuj A, Cledon M, Luzatto D, Nudelman S. 2004. Search for triorganotins along Mar del Plata (Argentina) marine coast: finding of tributyltin in egg capsules of a snail Adelomelon brasilina (Lamarck, 1822) population showing imposex effects. Applied Organometallics Chemistry 18: 117-123.

Horiguchi T, Shiraishi H, Shimizu A, Morita S. 1991. Imposex and organotin compounds in Thais clavigera and T. bronni in Japan. Journal of the Marine Biological Association of the U.K. 74: 651-669.

Mensink BP, Everaarts JM, Kralt H, Ten Hallers-Tjabbes CC, Boon J. 1996. Tributyltin exposure in early life stages induces the development of male characteristics in the common whelk, Buccinum undatum. Marine Environmental Research 42: 151-154.

Oehlmann J, Stroben E, Fiorini P. 1991. The morphological expression of imposex in Nucella lapillus (Linnaeus) (Gastropoda: Muricidae): a potential indicator of TBT. Journal of Molluscan Studies 57: 375-390.

Oehlmann J, Stroben E, Bettin C, Fioroni P. 1993. Hormonal disorders and tributyltin-induced imposex in marine snails. In: Quantified Phenotypic Responses in Morphology and Physiology. Proceedings of the 27th European Marine Biology Symposium, Dublin Ireland, 7-11 September 1992: 301-305.

Oehlmann J, Stroben E, Schulte-Oehlmann U, Bauer B, Fiorini P, Mardert B. 1996. Tributyltin biomonitoring using prosobranchs as sentinel organisms. Fresenius Journal of Analytical Chemistry 354: 540-545.

Prouse NJ, Ellis DV. 1997. A baseline survey of dogwhelk ( $N u$ cella lapillus) imposex in eastern Canada (1995) and interpretation in terms of tributyltin (TBT) contamination. Environmental Technology 18: 1255-1264.

Shi HH, Huang CJ, Zhu SX, Yu XJ, Xie WY. 2005. Generalized system of imposex and reproductive failure in female gastropods of coastal waters of mainland China. Marine Ecology Progress Series 304:179-189.

Smith BS. 1981. Tributyltin compounds induce male characteristics on female mud snails, Nassarius obsoletus = Iliyanassa obsoleta. Journal of Applied Toxicology 1: 141-144. 
Stewart C, De Mora SJ, Jones MRL, Miller MC. 1992. Imposex in New Zealand Neogastropods. Marine Pollution Bulletin 24: 204-209.

Stroben E, Oehlmann J, Fiorini P. 1992. The morphological expression of imposex in Hinia reticulata, (Gastropoda: Buccinidae): a potential indicator of TBT. Marine Biology 113: 625-636.

Swennen C, Moolenbeek RG, Ruttanadakul N, Hobbelink H, Dekker H, Hajisamae S. 2001. The molluscs of the southern Gulf of Thailand. Thai Studies in Biodiversity 4: 1-210.

Swennen C, Ruttanadakul N, Ardseungnern S, Singh HR, Mensink BP, Ten Hallers-Tjabbes CC. 1997. Imposex in sublittoral and littoral gastropods from the Gulf of Thailand and
Strait of Malacca in relation to shipping. Environmental Technology 18: 1245-1254.

Ten Hallers-Tjabbes CC, Kemp JF, Boon JP. 1994. Imposex in whelks (Buccinum undatum) from the open North Sea: relation to shipping traffic intensities. Marine Pollution Bulletin 28: 311-313.

Vaught KC. 1989. A classification of living Mollusca. American Malacologists Inc., Melbourne, Florida 32902, U.S.A., 195 pp.

Received: 30 August 2007

Accepted: 28 January 2008 